\title{
PERGESERAN TRADISI BELALEK DALAM BUDAYA BERTANI MASYARAKAT MELAYU SAMBAS
}

\author{
Hadi Wiyono ${ }^{\mathrm{a}, 1, *}$, Iwan Ramadhan ${ }^{\mathrm{b}, 2^{*}}$ \\ a Universitas Tanjungpura,, Pontianak, 78124, Indonesia \\ ${ }^{b}$ Universitas Tanjungpura, Pontianak, 78124, Indonesia \\ ${ }^{1}$ hadipips@untan.ac.id*; ${ }^{2}$ iwan.ramadhan@untan.ac.id*;
}

ARTICLE INFO

Article history:

Received : 2021-05-19

Revised : 2021-06-13

Accepted : 2021-06-23

Keywords:

Socio-Cultural Change

Belalek

Sambas Malay Community

Kata Kunci:

Perubahan Sosial Budaya

Belalek

Masyarakat Melayu Sambas

\section{ABSTRACT}

The purpose of this study was to analyze the shifting of Belalek tradition as seen from the factors of socio-cultural change, especially in the agricultural sector in the Sambas Malay society of Sentebang Village. The method used descriptive qualitative using observation, interview and documentation. The results revealed that people of Sentebang Village preferred to use the wage system compared to the remuneration system or called Belalek, the ease and efficiency of machine technology as a result of modernization, and the openness to changes and developments that occur. These three things have caused a shift in Belalek tradition.

\section{ABSTRAK}

Perubahan sosial budaya tidak dapat kita hindari pada masa kini yang semakin gencarnya modernisasi. tujuan dari penelitian ini adalah menganalisis bergesernya tradisi Belalek ditinjau dari faktorfaktor perubahan sosial budaya khususnya di bidang pertanian pada masyarakat Melayu Sambas Desa Sentebang. Metode yang digunakan adalah kualitatif deskripsi dengan teknik observasi, wawancara serta studi dokumentasi. Hasil penelitan berupa masyarakat Desa Sentebang lebih memilih menggunakan sistem upah dibanding dengan sistem balas jasa atau disebut dengan Belalek, kemudahan dan efisiennya teknologi mesin akibat dari modernisasi, serta adanya keterbukaan dengan perubahan dan perkembangan yang terjadi. Tiga hal inilah yang menyebabkan pergeseran tradisi Belalek.

\section{Pendahuluan}

Perubahan adalah suatu hal yang selalu terjadi, begitu juga dengan keadaan kondisi dan situasi yang mengharuskan masyarakat untuk berubah. Adanya perubahan pada masyarakat tidak terhindar dari beberapa bidang dalam kehidupan masyarakat itu sendiri beberapa diantaranya adalah terjadi di berbagai bidang dalam kehidupan masyarakat terutama masyarakat pedesaan yang masih memegang erat kebersamaan dan gotong royong (Baharuddin, 2015). Berdasarkan pendapat Soekanto, merumuskan bahwa perubahan sosial yang terjadi merupakan suatu perubahan yang ada pada masyarakat berdasarkan struktur serta fungsi-fungsi yang ada di kehidupan masyarakat (Soekanto, 2017). Ketika terjadi perubahan pada struktur dan fungsi dari masyarakat, maka terjadi pula perubahan pada budayanya karena suatu perubahan tersebut salah satunya adalah perubahan pada kebudayaan. pada bidang sosial budaya merupakan perubahan yang mencakup nilainilai, struktur dan tatanan kehidupan masyarakat yang didalamnya terjadi perubahan.

Pada perkembangannya perubahan sosial budaya di masyarakat juga menjadi permasalahan yang mungkin tidak bisa dianggap biasa begitu saja, dan akan terus 
berjalan seiring berjalannya waktu, setiap masyarakat akan mengalami sebuah perubahan yang nantinya suatu saat akan memberikan manfaat bagi masyarakat itu sendiri. Perubahan pada masyarakat dapat disebabkan oleh berbagai faktor yang melatarbelakangi perubahan. Perubahan dapat terjadi disebabkan oleh adanya sesuatu yang dianggap modern dan mudah untuk dilaksanakan bagi para anggota masyarakat. Perubahan juga dapat terjadi melalui beberapa faktor utama, baik itu faktor pendorong maupun faktor penghambat, atau faktor yang sudah ada maupun faktor yang lama terjadi, hal ini terjadi akibat dari adanya penyesuaian dari dampak perubahan itu sendiri. Faktor penyebab perubahan sosial dan budaya dapat terjadi karena adanya perubahan dari berkurangnya solidaritas sosial, berkurangnya interaksi sosial, proses yang terjadi karena unsur dari luar, meningkatnya eksistensi kesenian tradisional serta terjadinya sebuah mobilitas sosial (Gunawan, Suryadi, \& Malihah, 2015). Faktor-faktor tersebut dapat terjadi sekaligus dan dapat pula terjadi karena adanya salah satu faktor saja.

Salah satu fakor perubahan adalah adanya proses modernisasi pada suatu masyarakat. Pada masa sekarang ini, banyak terjadi perubahan dikarenakan adanya modernisasi. Gejala modernisasi dalam kehidupan manusia telah merambah ke berbagai aktivitas manusia baik pada ruang privat maupun publik. Modernisasi dapat berupa modernisasi teknologi maupun modernisasi gagasan atau ide (Martono, 2016). Pada kehidupan masyarakat, modernisasi dapat dilihat dari adanya marginalisasi budaya tradisional yang tergantikan dengan budaya modern. Budaya tradisional yang selama ini masih dipegang teguh dapat tergantikan dengan budaya baru. Misalnya saja pada bidang pertanian, dengan adanya modernisasi peran manusia sebagai tenaga kerja banyak yang tergantikan dengan tenaga mesin yang jauh lebih cepat dan lebih efisien. Perubahan peran manusia yang diganti dengan tenaga mesin tentu saja memiliki dampak dalam berbagai bidang. Beberapa aktivitas budaya dapat berkurang atau tergeser karena adanya perubahan tersebut.
Perubahan yang tampak pada masyarakat adalah perubahan ekonomi, perubahan sosial budaya yang terjadi pada masyarakatnya, baik yang bersifat menguntungkan maupun merugikan, salah satunya pasti akan terjadi (Esih Widya Kaesthi, 2014). Perubahan sosial budaya masyarakat adalah sebagai akibat dari adanya kemajuan teknologi dan media informasi yang setiap waktunya tidak dapat dihindari kapan akan terjadi, kearifan budaya yang ada di dearah masing-masing juga menjadi salah satu perubahan yang berkaitan dengan nilai-nilai yang akan tetap dipertahankan (Yoga, 2019). Kemudian, perubahan yang terjadi di desa-desa sekarang ini menjadi pembahasan yang cukup menarik ditengah arus globalisasi perubahan tersebut akibat dari adanya introduksi teknologi, transportasi dalam kehidupan pada masyarakat luas, komunikasi serta perubahan pada sistem-sistem mata pencaharian yang menyesuaian dengan situasi dan kondisi tertebut (Hatu, 2011). Perubahan sosial budaya juga terjadi pada masyarakat Melayu Sambas, tepatnya di Desa Sentebang Kabupaten Sambas, perubahan yang terjadi adalah pada sektor pertanian dapat dilihat dari sistem dan pola tanam pertanian padi yang dilakukan oleh masyarakat tersebut. Pada masa lalu masyarakat daerah tersebut dalam mengelola sawah masih dengan cara tradisional. Pada saat kegiatan bertani padi secara tradisional di daerah sekitaran kabupaten Sambas membutuhkan waktu yang cukup lama untuk proses dari membuka lahan sampai kepada panen yaitu sekitar 4 bulan sampai 5 bulan setiap kegiatannya (Kurniawan, 2019).

Terdapat istilah bumme yaitu membuka lahan atau membersihkan lahan dari batang padi selesai panen, nandor yaitu memulai menanam padi, nugal atau membuat lubang, memupuk rapun atau batang padi, membasmi gulma atau merumput, dan tahap memanen padi atau beranyi. Pada sistem mengolah sawah menggunakan cangkul yang dilakukan secara bergotong royong. Pengolahan sawah dilanjutkan dengan sistem tanam atau menyemai benih masih dengan tenaga manusia sampai dengan panen padi masyarakat masih menggunakan tenaga manusia yaitu dengan ani-ani. Seluruh kegiatan tersebut dilakukan dengan cara bergotong royong. Pada masa sekarang 
perubahan terjadi pada tenaga yang digunakan. Peran manusia sebagai tenaga utama telah tergantikan dengan tenaga mesin. Penggunaan alat pertanian modern telah menggantikan para petani dalam mengelola sawah secara bersama-sama.

Pada masyarakat Melayu sambas, terdapat istilah Belalek. Istilah Belalek merupakan kegiatan yang dilakukan secara bergotong royong oleh masyarakat dengan cara bergotong royong pada sebuah kegiatan menanam padi di ladang. Kegiatan Belalek berprinsip tidak adanya pemberian biaya atau gaji kepada siapa saja yang bekerja. Kegiatan yang dilakukan lebih kepada kegiatan pertanian karena istilah Belalek dominan digunakan untuk kegiatan-kegiatan pertanian. Tradisi budaya Belalek yang dilaksanakan oleh masyarakat melayu Sambas adalah kegiatan yang dimulai dengan membuka lahan, menanam pagi hingga masa panen yang dilakukan secara bersama-sama dan bergotong royong tanpa mengharapkan imbalan apapun, meskipun bukan tanah atau ladang miliknya sendiri, inilah yang menjadi ciri dari kebiasaan masyarakat melayu Sambas pada pelaksanaan tanam menanam padi (Darmawan, Zakso, \& Budjang, 2016). Kegiatan ini membuat masyarakat dapat lebih cepat terselesaikan dan tujuan lainnya adalah menjaga ikatan silahturahmi antar sesama masyarakat melayu Sambas serta saling menguntungkan dan saling bekerja sama antara warga satu dengan warga lainnya di desa tersebut.

Kegiatan tradisi budaya Belalek terdapat nilai-nilai sosial kearifan lokal yang memiliki tujuan mengembangkan nilai gotong royong dan nilai solidaritas yang dilakukan oleh sekelompok masyarakat atau warga yang mempunyai tanah untuk berladang tanaman padi. Namun hal ini mengalami penurunan yang dikatakan memudarnya tradisi budaya Belalek yang berupa kerjasama dan solidaritas sudah mengalami penurunan. Pada masa dahulunya setiap anggota masyarakat atau warga bersama-sama secara bergiliran saling bantu-membantu dalam menyelesaikan pekerjaan sawahnya, akan tetapi pada masa sekarang kegiatan ini sudah jarang dilakukan. Kegiatan Belalek yang terjadi pada masa kini hanya sebatas melibatkan anggota keluarga saja. Tradisi gotong royong Belalek sudah banyak ditinggalkan oleh masyarakat
Melayu. Masyarakat lebih memilih menggunakan sistem upah uang dalam bekerja daripada upah jasa. Hal ini dapat dipahami karena ketika semakin berkembangnya suatu desa yang diikuti dengan era modernisasi yang begitu cepat maka akan mengubah pemikiran masyarakatnya karena penggunaannya dianggap lebih efisien dibandingkan dengan balasan yaitu dengan jasa ataupun upah yang setimpal dengan pekerjaannya.

Dari beberapa fenomena tersebut, maka dalam kajian ini lebih melihat apakah perubahan sosial budaya dapat mempengaruhi pergeseran nilai Tradisi Belalek pada masyarakat Melayu Sambas di Desa Sentebang Kabupaten Sambas Provinsi Kalimantan Barat.

\section{Tinjauan Pustaka}

Budaya Belalek sangat akrab dengan masyarakat melayu Sambas, hal ini berkaitan dengan ungkapan kerjasama atau gotong royong dalam pelaksanaan kegiatan menanam padi. Budaya adalah suatu keseluruhan yang memiliki kompleksitas yang bertujuan untuk mengetahui pengetahuan, kepercayaan, kesenian, nilai dan norma, adat istiadat serta kegiatan lainnya yang dibentuk berdasarkan kebiasaan yang terjadi berulang-ulang pada masyarakat (Setiadi, 2011). Budaya Belalek adalah salah satu sistem kerja bergotong royong yang dilaksanakan pada masyarakat Melayu Sambas, kegiatan ini dilaksanakan pada bidang pertanian yang berdasarkan prinsip resiprioritas, yaitu sebuah kegiatan yang berlandaskan kegiatan timbak balik antar sesama masyarakat (Darmawan dkk., 2016). Gotong royong 'Belalek" merupakan suatu bentuk kerjasama antar individu dan kelompok guna memperoleh tujuan atau kepentingan atau kebaikan bersama bagi masyarakat itu sendiri (Herawati, 2018). Tradisi Belalek adalah sebuah kejadian yang perlu dibahas lebih rinci, selain dari adanya silahturahmi dari masyarakat, kegiatan gotong royong sangat diutamakan dalam segala hal, dalam tradisi ini terdapat nilainilai ke Islaman, adanya gotong royong antar sesama masyarakat yaitu petani yang merupakan sebagai rasa sosialisasi yang baik 
untuk membangun sebuah kebersamaan (Marliah, 2020).

Perubahan sosial dapat dikategorikan adanya sesuatu yang berubah di bidangbidang tertentu, beberapa diantaranya adalah bidang ekonomi, budaya, pendidikan termasuknya bidang pertanian. Perubahan sosial dibagi menjadi tiga kategori utama yaitu pertama, adanya wujud peralihan dari adanya perubahan yang terjadi bukan dari pengaruh budaya luar, kedua, secara sadar atau tidak berubahnya suatu kebijakan atau keputusan tidak diketahui secara pasti dan akan mempengaruhi sistem sosial pada masyarakat itu sendiri, ketiga, adanya pandangan baru yang memberikan suatu pengaruh untuk memperbaiki atau bisa juga menjadi suatu penurunan budaya atau memudarnya suatu kebiasaan yang sudah lama ada sebelumnya, (Rahma, Satya at, 2021).

Faktor-faktor perubahan sosial budaya sangat berkiatan erat dengan memudarnya tradisi atau budaya, berikut disampaikan faktor yang mempengaruhi perubahan sosial, Pertama. Adanya informasi-informasi yang berasal dari pengetahuan dan percobaan yang dilakukan guna memberikan gagasan atau pemikiran yang bersifat praktis. Kedua. Adanya modal dari setiap masyarakat untuk melakukan perubahan itu sendiri. Ketiga. Adanya teknologi, pengaruh ini sangat besar dikarenakan dapat memberikan perubahan pola pikir masyarakat atau sumber daya manusia yang ada. Keempat, Ideologi atau agama, yang mana bisa berpengaruh kepada proses perubahan sosial itu sendiri. Kelima, Birokrasi yang bersifat berubah-ubah sesuai dengan siapa yang akan memimpin atau penguasa. Keenam, Agent of change (Kango, 2015).

Berdasarkan penelitian sebelumnya tentang Tradisi ini, Tradisi Belalek pada masyarakat Melayu Sambas sudah banyak mengalami penurunan (Darmawan dkk., 2016). menemukan bahwa bergesernya budaya Belalek dikarenakan menurunnya nilai-nilai Belalek seperti nilai kerjasama, solidaritas antar para petani yang selama ini dipegang teguh ketika melakukan pengolahan lahan pertanian. Dengan demikian bergesernya tradisi Belalek tentu saja terdapat faktor-faktor lain yang mempengaruhinya atau berkembang pada masyarakat Melayu Sambas. Apa saja faktor- faktor tersebut sangat perlu untuk diteliti agar dapat diketahui penyebab bergesernya tradisi Belalek.

\section{Metodologi Penelitian}

Dalam penelitian ini, menggunakan metode kualitatif deskripsi agar dapat lebih mendalam mendapatkan informasi-informasi terkait judul yang ada, (Nawawi, 2015). Adapun teknik yang digunakan adalah teknik observasi dengan mengamati kegiatan masyarakat Desa Sentebang dalam mengelola sawah atau ladang serta aktivitas masyarakatnya. Teknik wawancara dengan mewawancarai informan yang berasal dari warga Desa Sentebang yang terdiri dari kepala desa, dan beberapa warga Desa Sentebang, Kabupaten Sambas. Untuk teknik dokumentasi yaitu dengan mengambil dokumen baik tertulis, gambar, ataupun elektronik (Sugiyono, 2015). yang mendukung penelitian ini terkait perubahan sosial budaya tradisi Belalek. Sedangkan menggunakan proses perpanjangan pengamatan untuk mendapatkan hasil yang maksimal.

\section{Hasil dan Diskusi}

\section{a. Perubahan dari Sistem Balas Jasa Menjadi Sistem Upah}

Perubahan sosial dan budaya ialah suatu fenomena yang terjadi di dalam kehidupan manusia. Perubahan itu terjadi berkaitan erat dengan kehidupan sosial masyarakat dan terbentuknya sebuah kebudayaan baru yang ada di masyarakat tersebut (Baharuddin, 2015). Seiring dengan berjalannya waktu perubahan akan pasti terjadi dan masyarakat juga akan mengalami suatu perubahan pula, baik perubahan secara cepat ataupun perubahan lambat. Dengan tuntutan perubahan zaman yang semakin modern kehidupan manusia tidak berhenti disitu saja, namun akan terus berputar.

Dari hasil yang didapat bahwa adanya beberapa petani yang mengubah sistem balas jasa dengan sistem upah membuat kegiatan Belalek berkurang. Sebagian besar petani padi lebih suka menerapkan sistem upah dibandingkan dengan sistem gotong royong karena dinilai lebih cepat dan hemat tenaga. Beberapa petani yang masih menginginkan sistem balas jasa terpaksa mengikuti 
keinginan beberapa petani lain yang meminta upah atau uang. Jika terjadi demikian, maka pihak pemilik sawah harus menyediakan upah untuk petani yang bekerja pada pemilik sawah tersebut. Teknologi dapat merubah sistem pada tatanan kehidupan di masyarakat khususnya sistem upah yang sebenarnya memiliki sifat yang negatif yaitu berkurangnya interaksi gotong royong, dan positifnya adalah memiliki waktu untuk pekerjaan lainnya (Susilowati, 2016).

Hal ini dibenarkan oleh beberapa petani yang bekerja pada petani lain. Menurut informan bahwa tetangganya yang bekerja membantu menanam padi disawahnya meminta uang sebagai imbalan jasanya membantu menanam bibit padi. Begitu pula ketika panen tiba, tetangganya tersebut juga tetap meminta upah berupa uang atau beras dan tidak mau meminta balas jasa membantu memanen padinya ketika waktu panen padi tiba. Informan pun menyadari bahwa kehidupan sekarang memerlukan uang (LS, 2020). dari pernyataan tersebut tidak mengherankan jika Tradisi Belalek tergeser dengan sistem upah yang dianggap lebih hemat tenaga dan lebih mudah. Kemudian dari sisi pekerja, dengan perubahan tersebut mengakibatkan dampak berkurangnya tenaga kerja yang biasa oleh masyarakat pertani Melayu Sambas, cara produksi juga merubah struktur sosial pada masyarakat tersebut (Djoh, 2018).

\section{b. Adanya Bantuan Teknologi Mesin Pertanian Akibat dari Modernisasi}

Modenisasi dapat mencakup beberapa hal yaitu pada perubahan perilaku, pengetahuan, struktur keterampilan yang dimiliki oleh masyarakat serta adanya inovasi (Matondang, 2019). Hadirnya peralatan modern juga mengubah sistem balas jasa dengan sistem upah. Pemerintah memberikan bantuan berupa peralatan mesin pertanian kepada para petani melalui kepada desa dengan membentuk kelompok-kelompok tani. Dengan menggunakan peralatan modern seperti traktor dan alat pemanen padi membuat pekerjaan menjadi lebih cepat sehingga waktu pengerjaan juga semakin efisien. Modernisasi pertanian adalah upaya perluasan dan pertumbuhan pendudukan agar dapat memberikan pembaharuan di bidang pertanian, dan memiliki keunggulan dibanding dengan cara pertanian tradisional (Rifkian, Suharso, \& Sukidin, 2017).

Perubahan peran manusia yang dalam hal ini petani Desa Sentebang yang diganti dengan tenaga mesin berdampak pada bidang budaya yaitu tergesernya tradisi Belalek. Aktivitas budaya Belalek berkurang atau tergeser karena adanya perubahan sistem upah serta hadirnya mesin-mesin pertanian yang tentu saja mengubah nilai-nilai tradisi Belalek seperti kerjasama dan solidaritas para petani. Sejalan dengan pemikiran tersebut (Rosana, 2011) bahwa adanya modernisasi pada tahap awal akan berakibat pada disorganisasi di dalam masyarakat. Disorganisasi dapat terjadi dalam struktur sosial maupun nilai-nilai yang berkembang di masyarakat. Jika merujuk pada pendapat Rosana maka bergesernya Tradisi Belalek merupakan proses disorganisasi dari adanya modernisasi.

Salah satu warga mengatakan bahwa menggunakan traktor dirasa sangat cepat. Pekerjaan mengolah lahan ketika menggunakan cangkul yang dikerjakan selama satu minggu lebih dengan waktu yang singkat sekitar dua sampai tiga hari sudah selesai untuk penggemburan tanah. Pengerjaan lahan tersebut membuat warga merasa bahwa hadirnya peralatan modern seperti traktor sangat membantu pengerjaannya mengolah sawah. Penggunaan mesin juga tidak hanya pada ketika mengolah tanah tetapi ketika memanen padi yang menggunakan alat perontok padi.

Pada hakikatnya proses perubahan dalam makna sosial adalah perjalanan kehidupan suatu masyarakat yang ditujukan oleh dinamika yang baik mengikuti evolusi biologis dalam daur kehidupan, atau perubahan tingkah laku dalam mengatasi situasi mengenai sosial masyarakat. Tidak dapat dihindari bahwa dengan adanya kemajuan yang semakin pesat di bidang teknologi dan pengetahuan memiliki pengaruh besar terhadap perkembangan kehidupan manusia, adapun akibat kemajuan tersebut dapat membawa dampak positif ataupun negatif bagi kehidupan masyarakat. Seperti halnya tradisi saling bekerja sama melalui budaya Belalek terdapat usaha saling bahu membahu untuk kepentingan bersama 
kemudian mulai memudar karena adanya faktor baru yang hadir pada sistem pertanian.

Perubahan yang terjadi di Desa Sentebang yang dilihat dari sektor pertanian yaitu menggarap sawah sudah tidak lagi menggunakan cangkul tetapi sudah menggunakan mesin traktor sehingga tanah lebih cepat diolah serta tidak memerlukan waktu lama dalam pengerjaannya, sampai dengan musim panen padi sudah menggunakan mesin perontok padi dan mesin kontainer sehingga saat panen di sawah, tanaman padi sudah menjadi bulir padi yang bersih.

Dilihat sekarang petani sudah bisa memanfaatkan semua terknologi yang ada dan sudah bisa mengimplementasikan berbagai ilmu yang diberikan pemerintah melalui penyuluhan dan sosialisasi-sosialisasi yang ada. Dengan banyaknya petani terbuka dengan teknologi sehingga dilihat dari sektor pertanian sekarang dapat dikatakan lebih maju dan berkembang dari beberapa tahun yang lalu. Tetapi, disamping berkembang pesatnya sektor pertanian, terdapat hal lain yaitu hilangnya kebudayaan yang sangat dirasakan masyarakat Desa Sentebang yaitu budaya gotong royong yang dalam bahasa sambasnya disebut dengan Belalek karena semua sudah tergantikan dengan teknologi. Terjadinya perubahan sosial budaya bahkan ekonomi pada struktur kehidupan masyarakat adalah kedepan akan ada ketergantungan pada alat-alat yang digunakan, hilangnya budaya gotong royong dan lahirlah sistem kasta dalam masyarakat bertani (Prayoga, Nurfadillah, Saragih, \& Riezky, 2019), sehingga banyak sekali terjadi perbedaan penghasilan dan sistem sosial juga akan berpengaruh signifikan, dikarenakan adanya tumpang tindih antara masyarakat yang memiliki kelebihan dengan masyarakat yang hanya mengandalkan apa adanya, atau dengan alat-alat tradisional.

\section{c. Para Petani Terbuka dengan Perubahan dan Perkembangan Teknologi}

Adanya sikap para petani yang menerima alat pertanian untuk menggarap lahan pertaniannya menjadikan alat -alat tersebut dapat diterima. Penerimaan mesin-mesin modern disatu sisi memang berbiaya mahal tetapi disisi lain petani melihat bahwa manfaat yang dirasakan sangat banyak diantaranya pengerjaan menjadi lebih cepat dan efisien. Pengerjaan panen tidak perlu memerlukan tenaga manusia yang banyak sehingga dirasa menjadi hemat oleh para petani. Informan yang merupakan seorang petani mengatakan bahwa dalam menggunakan mesin perontok padi dirasakan sangat membantu sehingga tidak perlu mencari tenaga petani lain untuk meminta bantuan menanen padinya ( $\mathrm{Zu}, 2020)$.

Disisi lain Informan juga menyadari bahwa ketika mengunakan mesin pertanian menyadari ada kegiatan atau tradisi yang tidak dilakukan lagi yaitu tradisi Belalek ( $\mathrm{Zu}$, 2020). Beliau pun memaklumi dengan perubahan yang terjadi secara terus menerus di era modern seperti ini tentunya tidak dapat dihindarkan dan sebagai masyarakat mau tidak mau harus mengikutinya agar tidak ketinggalan zaman.

Budaya Belalek itu sendiri merupakan gotong royong sesama petani untuk bekerjasama secara bergantian untuk menyelesaikan sawah mereka dari musim tanam hingga panen tiba. Petani yang mempunyai lahan mengajak petani padi lainnya yang sama-sama mempunyai lahan untuk bekerja sama sesuai kesepakatan, jika disanggupi yang punya lahan maka imbalannya mereka mengerjakan atau ikut dalam kegiatan menanam padi atau lainnya sesuai dengan yang dikerjakan sebelumnya. Terkait waktunya juga sesuai kesepakatan biasanya dari rentang 3-4 jam. Tradisi ini juga bisa mempererat tali persaudaraan karena selama pekerjaan selalu bercanda gurau (Kurniawan, 2019).

Perubahan yang terjadi di Desa Sentebang yang dilihat dari sektor pertanian yaitu menggarap sawah sudah tidak lagi menggunakan cangkul tetapi sudah menggunakan mesin traktor sehingga tanah lebih cepat diolah serta tidak memerlukan waktu lama dalam pengerjaannya, sampai dengan musim panen padi sudah menggunakan mesin perontok padi dan mesin container sehingga saat panen disawah tanaman padi sudah menjadi bulir padi yang bersih.

Dilihat sekarang petani sudah bisa memanfaatkan semua terknologi yang ada dan sudah bisa mengimplementasikan semua 
ilmu yang diberikan pemerintah melalui penyuluhan dan sosialisasi-sosialisasi yang ada. Dengan banyaknya petani yang terbuka dengan teknologi sehingga dilihat dari sektor pertanian sekarang dapat dikatakan lebih maju dan berkembang dari beberapa tahun yang lalu. Tetapi, disamping berkembang pesatnya sektor pertanian ada hal lain yaitu hilangnya kebudayaan yang sangat dirasakan masyarakat Desa Sentebang yaitu budaya gotong royong yang dalam bahasa sambasnya disebut dengan Belalek karena semua sudah tergantikan dengan teknologi.

Pergeseran tenaga manusia yang mulai digantikan dengan tenaga mesin. Sehingga sekarang terlihat jelas semua sudah di gantikan dengan tenaga mesin dan sektor pertanian semakin maju tetapi disisi lain lunturnya sistem gotong royong atau Belalek karena tenaga manusia sudah digantikan dengan tenaga mesin. Perubahan pada masyarakat Desa Sentebang dapat katakan sebagai perubahan yang disebabkan oleh pengaruh faktor-faktor yang memang dianggap lebih menguntungkan bagi masyarakat itu sendiri, faktor tersebut adalah faktor yang dapat merubah pola pikir dan sistem sosial yang berlaku sebelumnya, dengan penemuan dan uji coba yang baik dapat memberikan dapat yang positif bagi masyarakat itu sendiri, atau bisa kita katakan sebuah penemuan baru yang mau tidak mau akan dilaksanakan sebagai kebiasaan atau budaya baru. Sesuai dengan pendapat Soekanto yang menyatakan bahwa perubahan baik sosial maupun budaya hadir dan memberikan efek yang bersifat negatif maupun positif akibat dari adanya penemuan baru atau hadirnya teknologi baru (Soekanto, 2017). Jika dianalisis dari teori yang dimukakan oleh Soekanto dapat disimpulkan bahwa pergeseran budaya Belalek pada masyarakat melayu sambas khususnya di Desa Sentebang dikarenakan adanya faktor baru yang hadir menggantikan faktor lama.

Faktor baru tersebut juga dianggap lebih memuaskan atau dianggap lebih efektif dan efisien dilihat dari biaya dan cara kerjanya. Bagi masyarakat Desa Sentebang, faktor baru seperti hadirnya alat-alat mesin pertanian taktor, mesin perontok padi dianggap lebih efisien dan efektif. Faktor inilah yang menurunkan kegiatan tradisi Belalek yang sudah lama dilakukan oleh masyarakat
Melayu sambas yang identik dengan kebersamaan dan silahturahmi yang sangat erat antar sesamanya. Kemudian pelaksanaan ini juda tidak akan berjalan kalau tidak adanya keterbukaan dari masyarakat itu sendiri akan perubahan untuk lebih maju, dan tidak dapat dihindarkan dengan adanya perubahan itu sendiri (Togatorop, 2017).

Jika dianalisis dengan gejala modernisasi, dapat dikatakan bahwa terjadi proses modernisasi pada masyarakat Desa Sentebang. Sesuai dengan pernyataan Martono Modernisasi dapat berupa modernisasi teknologi maupun modernisasi gagasan atau ide (Martono, 2016). Pada kehidupan masyarakat, modernisasi dapat dilihat dari adanya marginalisasi budaya tradisional yang tergantikan dengan budaya modern. Budaya tradisional yang selama ini masih dipegang teguh dapat tergantikan dengan budaya baru. Pada masyarakat Desa Sentebang, dengan adanya modernisasi peran manusia sebagai tenaga kerja menanam bibit padi dan tenaga panen padi tergantikan dengan hadirnya tenaga mesin traktor dan mesin perontok padi yang jauh lebih cepat dan lebih efisien.

\section{Kesimpulan}

Berdasarkan hasil penelitian tentang Pergeseran Tradisi Belalek dalam Budaya Bertani Masyarakat Melayu Sambas di Desa Sentebang, dapat disimpulkan bahwa faktor perubahan sosial budaya pada tradisi Belalek yaitu adanya perubahan dari sistem balas jasa menjadi sistem upah. Sistem upah yang dilakukan dirasa lebih praktis karena dapat digunakan untuk memenuhi kebutuhan hidup yang lain. Kemudian faktor kedua adanya bantuan teknologi mesin pertanian sebagai akibat dari adanya modernisasi yang terjadi pada Desa Sentebang. Mesin pertanian seperti traktor dan mesin perontok padi yang dianggap lebih efisien dan efektif dalam pengerjaan sawah membuat para petani lebih banyak memilih menggunakan alat-alat tersebut daripada menggunakan tenaga petani lain. Selanjutnya terbukanya petani dengan perubahan dan perkembangan teknologi. Penyediaan mesin-mesin pertanian dapat diterima oleh para petani yang membuat mesin-mesin tersebut secara maksimal dimanfaatkan dalam pengerjaan pengolahan lahan pertanian. 


\section{Daftar Pustaka}

Baharuddin. (2015). Bentuk-bentuk perubahan sosial dan kebudayaan. Al-Hikmah (Jurnal Dakwah), 9(2), 180-205.

Darmawan, W., Zakso, A., \& Budjang, G. (2016). Memudarnya Nilai-Nilai Budaya "Belalek" Dalam Bidang Pertanian Pada Masyarakat Pedesaan. Jurnal Pendidikan Dan Pembelajaran Khatulistiwa, 5(3). Diambil dari https://jurnal.untan.ac.id/index.php/jp $\mathrm{dpb} /$ article/view/14177

Djoh, D. A. (2018). Dampak Modernisasi Terhadap Perubahan Sosial Masyarakat Tani di Desa Kambata Tana Kabupaten Sumba Timur. Jurnal Ekonomi Pertanian dan Agribisnis, 2(4), 332-339. https://doi.org/10.21776/ub.jepa.201 8.002.04.8

Esih Widya Kaesthi. (2014). Perubahan Sosial Budaya Masyarakat di Desa Wisata Karangbanjar Kabupaten Purbalingga. Solidarity: Journal of Education, Society and Culture, 3(1), 56-61.

Gunawan, H., Suryadi, K., \& Malihah, E. (2015). Analisis Perubahan Sosial Budaya Masyarakat Desa Cihideung Sebagai Desa Wisata. Sosietas, 5(2). https://doi.org/10.17509/sosietas.v5i 2.1524

Hatu, R. (2011). Perubahan Sosial Kultural Masyarakat Pedesaan (Suatu TInjauan Teoritik-Empirik). Junral Inovasi, 8(4), 1-11.

Herawati, H. dan K. (2018). Mitigasi bencana berbasis kearifan lokal di desa wajok provinsi kalimantan barat. Junral Teknik Sipil, 2(1), 1-10.

Kango, A. (2015). Media dan Perubahan Sosial Budaya. Farabi: Journal of Ushuluddin \& Islamic Thought, 12, 20-34.

Kurniawan, S. (2019). Bertani Padi Bagi Orang Melayu Sambas: Kearifan Lokal, Nilai-Nilai Islam, dan Character Building. Analisis: Jurnal Studi Keislaman, 18(2), 189-210. https://doi.org/10.24042/ajsk.v18i2.3 132

LS. (2020, Mei 21). Wawancara.
Marliah. (2020). Nilai Kebersamaan Dalam Tradisi Belalle ' Masyarakat Melayu Sambas Di Kabupaten Kubu Raya Desa Sungai Rengas. Prosiding Seminar Nasional Pendidikan Antropologi (SENASPA), 1, 92-100.

Martono, N. (2016). Sosiologi Perubahan Sosial. Jakarta: Jakarta: PT Raja Grafindo Persada.

Matondang, A. (2019). Dampak Modernisasi Terhadap Kehidupan masyarakat. Jurnal Wahana Inovasi, 8(5), 1-7.

Nawawi, H. (2015). Metode Penelitian Bidang Sosial. Pontianak: Gadja Mada University Press. Pontianak: Gadja Mada University Press.

Prayoga, K., Nurfadillah, S., Saragih, M., \& Riezky, A. M. (2019). Menakar Perubahan Sosio-Kultural Masyarakat Tani Akibat Miskonsepsi Modernisasi Pembangunan Pertanian. SOCA: Jurnal Sosial, Ekonomi Pertanian, 13(1), 96. https://doi.org/10.24843/soca.2019.v 13.i01.p08

Rahma, Satya at, All. (2021). Modernisasi Terhadap Perubahan Sosial Masyarakat Desa Namlea Kabupaten Buru. Nusantara: Jurnal Ilmu Pengetahuan Sosial, 8(1), 84-96.

Rifkian, B. E., Suharso, P., \& Sukidin, S. (2017). Modernisasi Pertanian (Studi Kasus Tentang Peluang Kerja Dan Pendapatan Petani Dalam Sistem Pertanian Di Desa Dukuhdempok Kecamatan Wuluhan Kabupaten Jember). JURNAL PENDIDIKAN EKONOMI: Jurnal Ilmiah Ilmu Pendidikan, Ilmu Ekonomi dan Ilmu Sosial, $\quad 11(1), \quad 39$. https://doi.org/10.19184/jpe.v11i1.49 95

Rosana, E. (2011). Modernisasi dan Perubahan Sosial. TAPIs, 7(.12), 130.

Setiadi, E. M. (2011). Ilmu Sosial dan Budaya Dasar. Jakarta: Kencana Prenada Media Group.

Soekanto, S. (2017). Sosiologi Suatu Pengantar. Jakarta: Jakarta: PT Raja Grafindo Persada.

Sugiyono. (2015). Metode Penelitian Kombinasi (Mix Methods). Bandung: Alfabeta. 
Susilowati, S. H. (2016). Gejala Pergeseran Kelembagaan Upah pada Pertanian Padi Sawah. Forum penelitian Agro Ekonomi, 23(1), 48. https://doi.org/10.21082/fae.v23n1.2 005.48-60

Togatorop, A. (2017). Modernisasi Pertanian Terhadap Pemakaian Pupuk Dalam Meningkatkan Taraf Hidup Petani di Desa Sirisirisi Kecamatan Doloksanggul Sumatera Utara. JOM FISIP , 4(2), 1-15.
Yoga, S. (2019). Perubahan Sosial Budaya Masyarakat Indonesia Dan Perkembangan Teknologi Komunikasi. Jurnal Al-Bayan, 24(1), 29-46.

https://doi.org/10.22373/albayan.v24 i1.3175

Zu. (2020, Oktober 6). Wawancara. 